\title{
Silicon stable isotope distribution traces Southern Ocean export of Si to the eastern South Pacific thermocline
}

\author{
G. F. de Souza ${ }^{1, *}$, B. C. Reynolds ${ }^{1}$, G. C. Johnson ${ }^{2}$, J. L. Bullister ${ }^{2}$, and B. Bourdon ${ }^{1, * *}$ \\ ${ }^{1}$ ETH Zurich, Institute of Geochemistry and Petrology, Zurich, Switzerland \\ ${ }^{2}$ Pacific Marine Environmental Laboratory, National Oceanic and Atmospheric Administration, Seattle, Washington, USA \\ *now at: Atmospheric and Oceanic Sciences Program, Princeton University, Princeton, New Jersey, USA \\ ** now at: Laboratoire de Géologie de Lyon, ENS Lyon, CNRS and UCBL, Lyon, France
}

Correspondence to: G. F. de Souza (gfds@princeton.edu)

Received: 23 April 2012 - Published in Biogeosciences Discuss.: 5 June 2012

Revised: 17 September 2012 - Accepted: 5 October 2012 - Published: 1 November 2012

\begin{abstract}
The cycling and transport of dissolved silicon (Si) in the ocean may be traced by its stable isotope composition, $\delta^{30} \mathrm{Si}$. We present a dataset of $\delta^{30} \mathrm{Si}$ values along $103^{\circ} \mathrm{W}$ in the eastern South Pacific Ocean, ranging from the Antarctic Zone of the Southern Ocean $\left(62^{\circ} \mathrm{S}\right)$ to the equatorial Pacific $\left(12^{\circ} \mathrm{S}\right)$. At high southern latitudes, the uptake and associated isotope fractionation of $\mathrm{Si}$ by diatoms results in highly elevated $\delta^{30} \mathrm{Si}$ values (up to $+3.2 \%$ ) in the summer mixed layer. High $\delta^{30} \mathrm{Si}$ values $(+2 \%$ ) are also preserved in the high-latitude fossil winter mixed layer, documenting the efficient export of diatom opal beyond the maximum depth of winter convection. This elevated winter mixed layer $\delta^{30} \mathrm{Si}$ signature is introduced into the ocean interior by the subduction of Subantarctic Mode Water (SAMW) and Antarctic Intermediate Water (AAIW), whose northward spreading results in a strong isopycnal control on lower-thermocline and intermediate $\delta^{30} \mathrm{Si}$ values in the well-ventilated eastern South Pacific. Values of $\delta^{30} \mathrm{Si}$ are strongly conserved along SAMW and AAIW density levels as far north as $26^{\circ} \mathrm{S}$, documenting the importance of the export of preformed $\mathrm{Si}$ from the surface Southern Ocean to lower latitudes. In contrast, in the equatorial Pacific, depressed $\delta^{30} \mathrm{Si}$ values in the mesopelagic ocean are observed, most likely documenting the combined influence of a North Pacific Si source as well as the accumulation of remineralized Si within the eastern equatorial Pacific shadow zone. At depth, $\delta^{30} \mathrm{Si}$ values in the South Pacific remain indistinguishable from deep Southern Ocean values of $+1.25 \%$, even within Si-rich and oxygen-poor deep waters returning from the North Pacific. This homogeneity implies that the dissolution of opal plays a negligible role in altering the $\delta^{30} \mathrm{Si}$ value of deep waters as they traverse the deep Pacific Ocean.
\end{abstract}

\section{Introduction}

The eastern South Pacific is a region of considerable importance for the global ocean, in terms of both its circulation and its biogeochemistry. Its high latitudes are a dominant formation region of Subantarctic Mode Water and Antarctic Intermediate Water (SAMW and AAIW; McCartney, 1982; Hanawa and Talley, 2001; Aoki et al., 2007; Sallée et al., 2010). These water masses are important participants in the ocean's meridional overturning circulation (MOC), contributing to the upper return flow of waters to the North Atlantic (e.g., Sloyan and Rintoul, 2001; Lumpkin and Speer, 2007). In addition, it has been suggested that SAMW exported northward from the Southern Ocean plays a key role in supplying nutrients to lower latitudes at the near-global scale, controlling the magnitude of low-latitude productivity and leading to the widespread depletion in silicon ( $\mathrm{Si}$ ) - a vital nutrient for siliceous phytoplankton - observed in the low-latitude thermocline (Sarmiento et al., 2004; Palter et al., 2010). Within the Pacific Ocean, SAMW/AAIW subducted in the eastern South Pacific also represent a dominant pathway for the supply of nutrients and oxygen to the upwelling zones of the equatorial Pacific (Tsuchiya et al., 1989; Toggweiler et al., 1991; Fine et al., 2001; Dugdale et al., 2002; Karstensen et al., 2008; Sallée et al., 2010), a biogeochemically dynamic region that represents the largest oceanic source of $\mathrm{CO}_{2}$ to the atmosphere (Gruber et al., 2009) and hosts the ocean's most extensive oxygen minimum zones (OMZs). The inefficiency of the equatorial Pacific biological pump, manifested by its strong $\mathrm{CO}_{2}$ outgassing, appears to owe its origin at least partially to the low $\mathrm{Si}$ content of SAMW/AAIW (Dugdale et al., 2002; Brzezinski et al.,

Published by Copernicus Publications on behalf of the European Geosciences Union. 
2008), which limits the productivity of diatoms, siliceous phytoplankton that are efficient exporters of carbon to depth (e.g., Buesseler, 1998).

In this study, we investigate the influence of the formation and circulation of SAMW/AAIW on the cycling and transport of $\mathrm{Si}$ in the eastern South Pacific from the Antarctic Zone $\left(62^{\circ} \mathrm{S}\right)$ to the tropics $\left(12^{\circ} \mathrm{S}\right)$, by analyzing the distribution of the stable isotope composition of dissolved $\mathrm{Si}$, expressed as $\delta^{30} \mathrm{Si}$ (Eq. 1). When diatoms in the euphotic zone take up Si to form their opaline frustules, they preferentially incorporate the lighter isotopes of $\mathrm{Si}$ (De La Rocha et al., 1997; Milligan et al., 2004), thereby altering the stable isotope composition of dissolved Si in seawater (e.g., Varela et al., 2004; Cardinal et al., 2005; Beucher et al., 2008; Fripiat et al., 2011a). Seawater $\delta^{30} \mathrm{Si}$ values thus trace the biogeochemical processes affecting $\mathrm{Si}$, and may be used as an element-specific constraint on the processes that cycle Si within the sea. Recently, de Souza et al. (2012) have shown that dissolved Si in North Atlantic Deep Water (NADW) has a $\delta^{30} \mathrm{Si}$ value that is $\sim 0.5 \%$ higher than that of Circumpolar Deep Water $(\mathrm{CDW})$ in the deep Southern Ocean. They inferred that this difference results from the transport of Si with an elevated $\delta^{30} \mathrm{Si}$ value into the North Atlantic by SAMW/AAIW. This inference implies that the process of intermediate/mode water formation in the surface Southern Ocean creates subsurface seawater $\delta^{30} \mathrm{Si}$ variability that can be used to trace large-scale oceanic Si transport.

Here, we exploit the broad latitudinal scope of our study to analyze the $\delta^{30} \mathrm{Si}$ distribution in the context of the regionalto large-scale circulation. We trace the evolution of $\delta^{30} \mathrm{Si}$ values from the SAMW/AAIW formation regions in the high latitudes of the eastern South Pacific into the low-latitude ocean interior. We show that elevated $\delta^{30} \mathrm{Si}$ values preserved in high-latitude winter mixed layers are exported to lower latitudes in SAMW/AAIW and conserved as these water masses traverse the subtropical Pacific Ocean, documenting the importance of Southern Ocean export in supplying Si to the base of the permanent thermocline. Furthermore, we show that, in the equatorial Pacific, the $\delta^{30} \mathrm{Si}$ distribution reflects the influence of both sources of $\mathrm{Si}$ to, and cycling of $\mathrm{Si}$ within, this biogeochemically complex system. In the deep waters of the South Pacific Ocean, we document low $\delta^{30} \mathrm{Si}$ variability that points towards a minimal role of opal dissolution in altering seawater $\delta^{30} \mathrm{Si}$ values.

\section{Sampling and analytical methods}

This study primarily focuses on 63 seawater samples collected on expedition 33RO20071215 of R/V Ronald H. Brown (15 December 2007 to 23 February 2008), a reoccupation of the World Ocean Circulation Experiment (WOCE) line P18 undertaken within the Climate Variability and Predictability (CLIVAR) project. Samples for silicon isotope analysis were collected at six stations along a merid- ional section at $103^{\circ} \mathrm{W}$, from $12^{\circ} \mathrm{S}$ to $62^{\circ} \mathrm{S}$ (Fig. 1 and Table 1). All samples were filtered onboard using $0.2 \mu \mathrm{m}$ Whatman GF/F filters and acidified with $1 \% v / v$ distilled $6 \mathrm{M} \mathrm{HCl}$ in the laboratory at least $12 \mathrm{~h}$ before sample processing. The presented dataset also includes six Southern Ocean deep water samples from the Indo-Atlantic sector, collected on expedition 33RR20080204 of R/V Roger Revelle (4 February to 17 March 2008), a CLIVAR re-occupation of WOCE line I06S along $30^{\circ} \mathrm{E}$. These samples were filtered using $0.2 \mu \mathrm{m}$ polyethersulfone filters at our land-based laboratory and acidified as above.

Sample processing and analytical methods were adapted from Georg et al. (2006) and Reynolds et al. (2006), and are described in detail by de Souza et al. (2012). Briefly, Si is separated from sea salt by co-precipitation with brucite and subsequent cation-exchange chromatography. Silicon stable isotope composition is analyzed using a high-resolution multicollector inductively coupled plasma mass spectrometer (Nu Plasma 1700; Nu Instruments, UK) by sample-standard bracketing, with a single analysis corresponding to 5 bracketed measurements of a sample. Silicon stable isotope composition is reported as the permil deviation from the standard reference material NBS28, denoted by $\delta^{30} \mathrm{Si}$ :

$\delta^{30} \mathrm{Si}=\left(\frac{\left(\frac{{ }^{30} \mathrm{Si}}{{ }^{28} \mathrm{Si}}\right)_{\text {sample }}}{\left({ }^{30} \mathrm{Si}\right.}-1\right) \times 1000[\% 0]$.

The long-term external reproducibility of our $\delta^{30} \mathrm{Si}$ analyses is $\pm 0.12 \%$ o $\left(2 \sigma_{\mathrm{SD}}\right)$, as estimated from the variance of $\sim 300$ analyses of the secondary isotopic standard Diatomite (Brzezinski et al., 2006) over $>3 \mathrm{yr}$. The average $\delta^{30} \mathrm{Si}$ value of Diatomite measured over this period is $+1.22 \pm 0.01 \%$ o ( 2 standard errors of the mean, $2 \sigma_{\text {SEM }}$ ), consistent with the inter-laboratory comparison study of Reynolds et al. (2007). Most seawater analyses $(\sim 70 \%)$ were completely replicated 2-5 times in separate analytical sessions, providing estimates of uncertainty $\left(2 \sigma_{\mathrm{SD}}\right)$ that were generally smaller than the long-term reproducibility of $\pm 0.12 \%$ o. We report external $2 \sigma_{\mathrm{SD}}$ errors on the seawater data as replicate-based or longterm reproducibility, whichever is larger (Supplement Table 1). Error bars shown in all figures are external $2 \sigma_{\mathrm{SD}}$.

Note that the Whatman GF/F filters used on expedition 33RO20071215 are glass microfiber filters, such that the potential for Si contamination exists (these filters were used as a stopgap solution when the planned filtration system failed on board). Filtration of ultrapure water and Si-depleted seawaters through $\mathrm{GF} / \mathrm{F}$ filters at our land-based laboratory indicated a filtration blank of $0.35-0.45 \mu \mathrm{M} \mathrm{Si}$. This low level of contamination is negligible for the majority of our samples; however, the filtration blank is considerable for 8 nearsurface samples with Si concentrations $<7 \mu \mathrm{M}$ (Supplementary Table 1). Due to the extremely small absolute blank contribution, it is not possible to directly determine its isotopic composition and hence the extent of its potential influence 
Table 1. Station locations from which samples presented in this study were collected.

\begin{tabular}{clccr}
\hline $\begin{array}{c}\text { Station } \\
\text { No. }\end{array}$ & Station Location & Latitude & Longitude & $\begin{array}{r}\text { Water } \\
\text { Depth [m] }\end{array}$ \\
\hline CLIVAR P18 re-occupation & & & \\
\hline 70 & Bauer Basin & $11^{\circ} 45^{\prime} \mathrm{S}$ & $103^{\circ} \mathrm{W}$ & 4153 \\
95 & Sala y Gómez Ridge & $26^{\circ} 20^{\prime} \mathrm{S}$ & $103^{\circ} \mathrm{W}$ & 2125 \\
& (Southern Peru Basin) \\
114 & Southeast Pacific Basin & $37^{\circ} 25^{\prime} \mathrm{S}$ & $103^{\circ} \mathrm{W}$ & 3952 \\
136 & Southeast Pacific Basin & $50^{\circ} 15^{\prime} \mathrm{S}$ & $103^{\circ} \mathrm{W}$ & 4171 \\
149 & Southeast Pacific Basin & $57^{\circ} 45^{\prime} \mathrm{S}$ & $103^{\circ} \mathrm{W}$ & 4657 \\
158 & Southeast Pacific Basin & $62^{\circ} 15^{\prime} \mathrm{S}$ & $103^{\circ} \mathrm{W}$ & 5026 \\
\hline CLIVAR I06S re-occupation & & & \\
\hline \multicolumn{6}{c}{33} & Agulhas Basin & $43^{\circ} 30^{\prime} \mathrm{S}$ & $30^{\circ} \mathrm{E}$ & 5168 \\
\hline
\end{tabular}

on the measured $\delta^{30} \mathrm{Si}$ values of these samples. As detailed in the Supplement, we are reasonably confident that the $\delta^{30} \mathrm{Si}$ values of the 8 low-Si samples are not strongly affected, but conservatively note that we cannot conclusively rule out that their true $\delta^{30} \mathrm{Si}$ values are higher (by $0.2-0.4 \%$ ) than the values we report (see Supplement). Note that the $\delta^{30} \mathrm{Si}$ values of all samples with Si concentration above $7 \mu \mathrm{M}$ (including high-latitude winter mixed layers) are insignificantly affected by the filtration blank.

In this study, the notations $\mathrm{Si},[\mathrm{Si}]$ and $\delta^{30} \mathrm{Si}$ will refer to dissolved silicon (i.e., silicic acid), its concentration, and its stable isotope composition, respectively. Seawater density will be presented as neutral density $\gamma^{\mathrm{n}}$ (Jackett and McDougall, 1997), since this variable is applicable over the entire depth range of the water column.

\section{Hydrographic description}

Line P18 traverses the western margins of four deep ocean basins (Fig. 1): the Southeast Pacific Basin, the Chile Basin, the Peru Basin, and the Bauer Basin, which are separated from each other by the Chile Rise $\left(35^{\circ} \mathrm{S}\right.$ at $\left.103^{\circ} \mathrm{W}\right)$, Sala y Gómez Ridge $\left(26-27^{\circ} \mathrm{S}\right)$ and the Galápagos Rise (17$\left.18^{\circ} \mathrm{S}\right)$. The deep Pacific Ocean displays little variability in the conservative parameters potential temperature, $\theta$, and salinity, $S$, since it only possesses one source of deep water, CDW from the Southern Ocean (e.g., Schmitz, 1996). The main salinity feature at depth (Fig. 2a) is a muted maximum in the far south, deepening with the $\gamma^{\mathrm{n}} \approx 28.1 \mathrm{~kg} \mathrm{~m}^{-3}$ surface from about $1200 \mathrm{~m}$ at $70^{\circ} \mathrm{S}$ to the bottom at $\sim 45^{\circ} \mathrm{S}$. This is a highly diluted NADW signal in the Upper Circumpolar Deep Water (Warren, 1973; Tsuchiya and Talley, 1998). Along the bottom, elevated oxygen concentrations, $\left[\mathrm{O}_{2}\right]$, trace the northward spreading of $\mathrm{CDW}$ up to Chile Rise (Fig. 2b). Above this lies a mild mid-depth $\left[\mathrm{O}_{2}\right]$ minimum that has been associated with return flow from the North Pacific (Reid, 1986; Tsuchiya and Talley, 1998). The basins to the north of Chile Rise are generally less well-oxygenated at

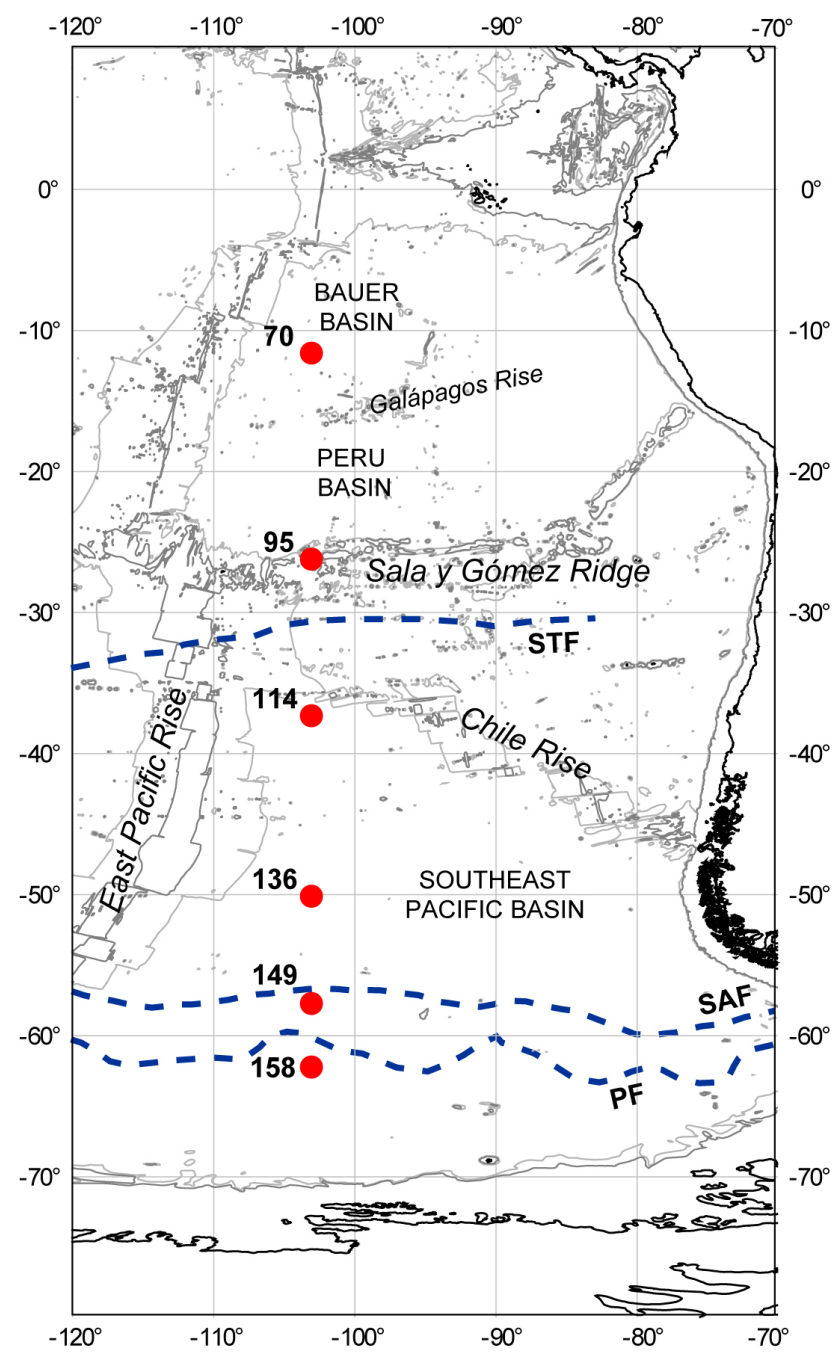

Fig. 1. Map of the eastern South Pacific Ocean showing locations of stations from which samples were collected on expedition 33RO20071215. Dark and light gray lines represent the $3000 \mathrm{~m}$ and $3500 \mathrm{~m}$ isobaths, respectively. The dashed blue lines mark the location of the Subtropical Front (STF), Subantarctic Front (SAF) and Polar Front (PF) from Orsi et al. (1995).

depth; in the Peru and Bauer Basins, $\left[\mathrm{O}_{2}\right]$ decreases northward in two steps that are both associated with increases in [Si] (Fig. 2c). The low $\left[\mathrm{O}_{2}\right]$ and high $[\mathrm{Si}]$ in the northern Bauer Basin are related to the westward flow of deep waters of North Pacific origin that enter the Bauer Basin at its northeastern margin (Reid, 1986, 1997; Tsuchiya and Talley, 1998).

In contrast to the deep ocean, the upper $\sim 1 \mathrm{~km}$ of the South Pacific water column shows rich water mass structure, reflected most clearly in the salinity distribution (Fig. 2a). The most striking feature is the tongue of low salinity (34.2$34.3 \mathrm{psu}$ ) that extends from the sea surface at high latitudes to $20^{\circ} \mathrm{S}$, associated with the isopycnal spreading of AAIW and SAMW (Tsuchiya and Talley, 1996, 1998) that are formed 

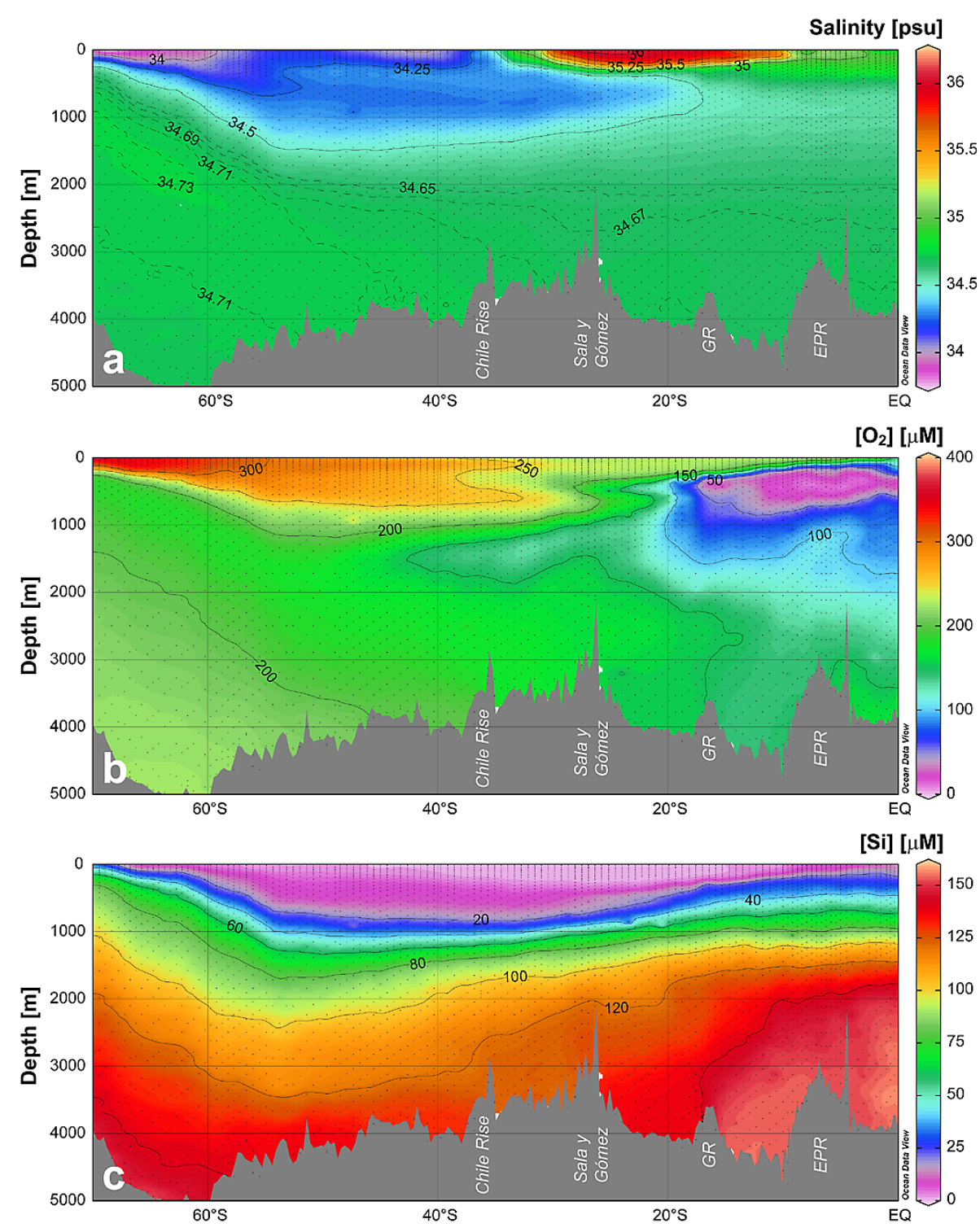

Fig. 2. South Pacific (a) salinity, (b) oxygen and (c) [Si] distributions along line P18 from expedition 33RO20071215. Note the difference in contour interval between the upper ocean (solid) and deep ocean (dashed) contours in panel (a). See text for description of the main features. GR is the Galápagos Rise; EPR is the East Pacific Rise. Data are from the CLIVAR \& Carbon Hydrographic Data Office (http: //cchdo.ucsd.edu/); color maps were produced using Ocean Data View (Schlitzer, 2009).

by deep winter convection in the Subantarctic South Pacific (Hanawa and Talley, 2001; Sloyan et al., 2010). Subantarctic Mode Water can be identified as a pronounced potential vorticity minimum (not shown) found slightly above the salinity minimum. The high $\left[\mathrm{O}_{2}\right]$ (Fig. 2 b) of SAMW and AAIW highlights the importance of these waters for the ventilation of the subtropical subsurface at lower thermocline and intermediate depths. The northern end of the pronounced salinity minimum, at $\sim 20^{\circ} \mathrm{S}$, is related to the anticyclonic subtropical circulation, which advects AAIW and SAMW westward at this latitude. The salinity minimum persists to the north at slightly higher salinity $(\sim 34.55 \mathrm{psu})$, tracing AAIW that has entered the zonal equatorial circulation further west (Tsuchiya, 1991; Tsuchiya and Talley, 1996, 1998).

Another major feature of the salinity distribution is the bowl of salty water that extends from the subtropical front to about $10^{\circ} \mathrm{S}$ at the surface (and further north within the subsurface), with a maximum depth of $\sim 300 \mathrm{~m}$. The potential vorticity distribution allows the distinction of South Pacific Eastern Subtropical Mode Water (SPESTMW), centered around $150 \mathrm{~m}$ depth, from the salinity maximum of Subtropical Water (STW) above it (O'Connor et al., 2002; Wong and Johnson, 2003). Both these subtropical water masses are highly depleted in macronutrients over their entire 

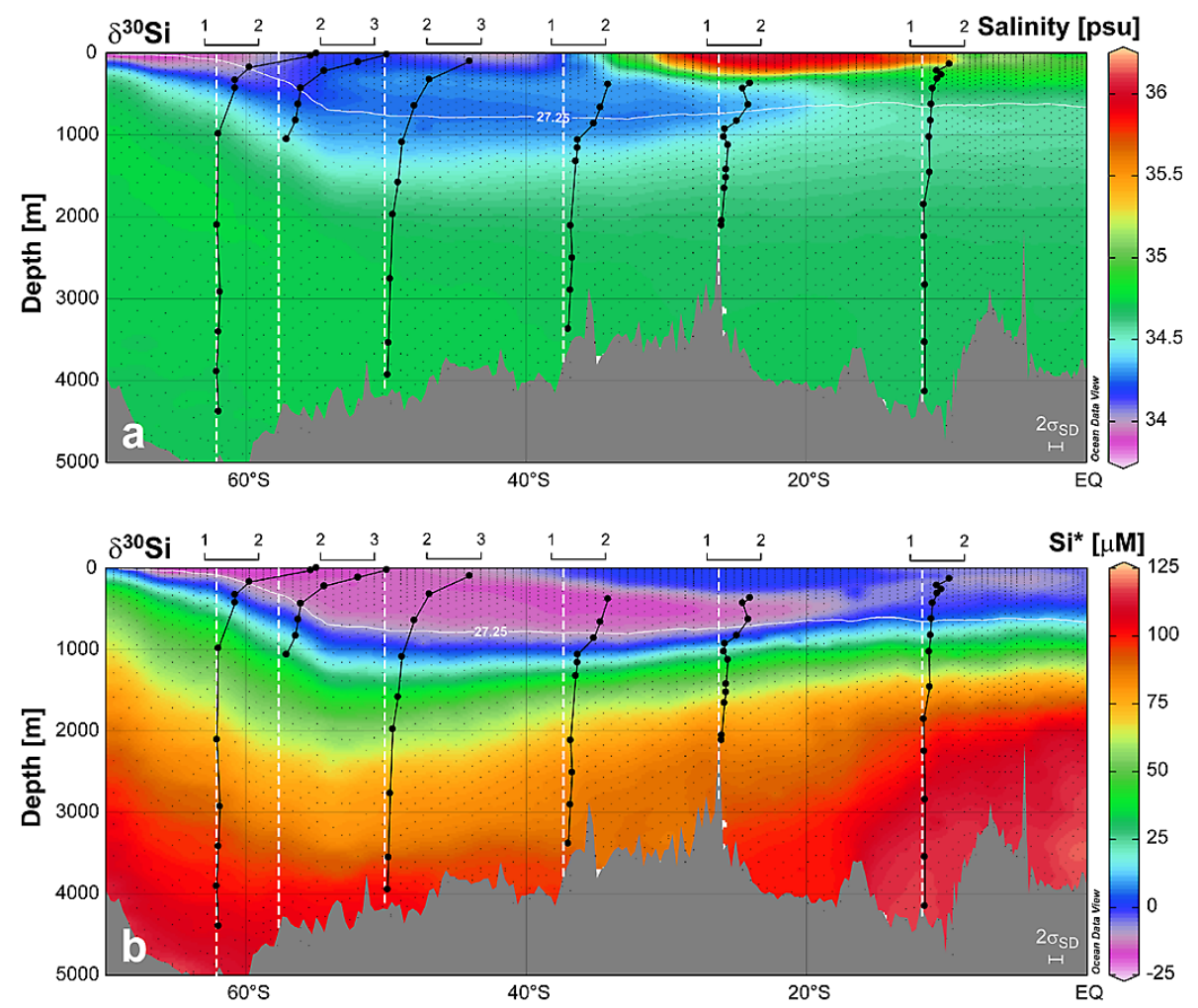

Fig. 3. Depth profiles of $\delta^{30} \mathrm{Si}$ overlain on color maps of (a) salinity and (b) $\mathrm{Si}{ }^{*}=[\mathrm{Si}]-\left[\mathrm{NO}_{3}\right]$. The white line in each profile marks the sampling position as well as a $\delta^{30} \mathrm{Si}$ value of $+1.22 \%$, corresponding to CDW (de Souza et al., 2012). The solid white line traces the $\gamma^{\mathrm{n}}=27.25 \mathrm{~kg} \mathrm{~m}^{-3}$ surface. GR is the Galápagos Rise; EPR is the East Pacific Rise. Color map data are from the CLIVAR \& Carbon Hydrographic Data Office (http://cchdo.ucsd.edu/).

depth and lateral extent. Their extremely low [Si] $(0.5-$ $1.5 \mu \mathrm{M}$; Fig. 2c) precluded $\delta^{30} \mathrm{Si}$ analysis, given collected sample volumes of 50-100 $\mathrm{ml}$.

North of $20^{\circ} \mathrm{S}$, the mesopelagic water column below SPESTMW and STW is dominated by more uniformly saline waters of the equatorial regime. These waters host the South Pacific OMZ, with $\left[\mathrm{O}_{2}\right]<20 \mu \mathrm{M}$ within the most intense portion of the OMZ centered at $400 \mathrm{~m}\left(\gamma^{\mathrm{n}} \approx 26.9 \mathrm{~kg} \mathrm{~m}^{-3}\right)$ and $6^{\circ} \mathrm{S}$ (Fig. 2b). A minor oxygen minimum extends further south to about $27^{\circ} \mathrm{S}$ at $\sim 450 \mathrm{~m}\left(\gamma^{\mathrm{n}} \approx 26.75 \mathrm{~kg} \mathrm{~m}^{-3}\right)$, associated with elevated [Si] and a weak halostad. This subsurface equatorial signal may be carried into the subtropics by the Subsurface Countercurrents (Johnson and McPhaden, 1999) feeding the Peru-Chile Undercurrent (Blanco et al., 2001), which in turn transports equatorial waters poleward and sheds eddies into the ocean interior (Johnson and McTaggart, 2010).

\section{Results}

Values of $\delta^{30} \mathrm{Si}$ generally increase upwards through the water column, with the highest values (up to $+3.2 \%$ ) found within the surface mixed layer (Fig. 3, Supplement Table 1).
At depth, the Southern Ocean is exceptionally homogeneous, with an average $\delta^{30} \mathrm{Si}$ value of $+1.25 \pm 0.05 \%$ o $\left(2 \sigma_{\mathrm{SD}}, n=6\right)$ at water depths $\geq 1000 \mathrm{~m}$, corresponding to neutral densities $\gamma^{\mathrm{n}} \geq 27.93 \mathrm{~kg} \mathrm{~m}^{-3}$. Deep waters at stations further north show similarly low $\delta^{30} \mathrm{Si}$ values: the average $\delta^{30} \mathrm{Si}$ value for all samples outside the Southern Ocean below the salinity minimum of AAIW ( $\geq 1400 \mathrm{~m}, \gamma^{\mathrm{n}} \geq 27.77 \mathrm{~kg} \mathrm{~m}^{-3}$ ) is $+1.32 \pm 0.11 \%$ o $\left(2 \sigma_{\mathrm{SD}}, n=20\right)$. Over the same density range as the deep Southern Ocean $\left(\gamma^{\mathrm{n}} \geq 27.93 \mathrm{~kg} \mathrm{~m}^{-3}\right)$, the average $\delta^{30} \mathrm{Si}$ value is $+1.30 \pm 0.08 \%$ o $\left(2 \sigma_{\mathrm{SD}}, n=13\right)$. A Monte Carlo t-test (see Supplement) indicates a probability of only $22 \%$ that these values are significantly different at the $95 \%$ level, emphasizing the high degree of homogeneity in deep water $\delta^{30} \mathrm{Si}$ values. Visually, the deep water column at $37.5^{\circ} \mathrm{S}$ appears as an exception, exhibiting a nominally higher $\delta^{30} \mathrm{Si}$ value than the Southern Ocean (Fig. 3), but the Monte Carlo approach indicates only a $39 \%$ probability that this difference is significant.

In general, seawater $\delta^{30} \mathrm{Si}$ values show the strongest vertical gradient within the uppermost $1000 \mathrm{~m}$ of the water column, although the depth extent of this gradient varies strongly with latitude (Fig. 3) and, on visual inspection, appears to follow the salinity minimum associated with the northward spreading of SAMW/AAIW. The 


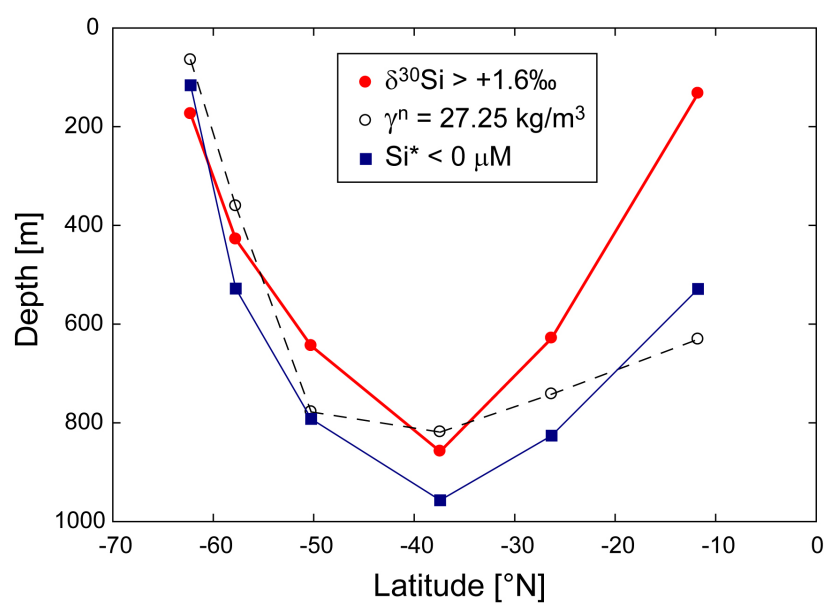

Fig. 4. A comparison of the deepest depth of elevated $\delta^{30} \mathrm{Si}$ values $(>+1.6 \%$ ) with the depths of two surfaces that follow the spreading of AAIW northwards, showing the strong similarity in evolution with latitude. Both the $\mathrm{Si}^{*}<0$ and $\delta^{30} \mathrm{Si}>+1.6 \%$ surface shoal more strongly than the isopycnal $\gamma^{\mathrm{n}}=27.25 \mathrm{~kg} \mathrm{~m}^{-3}$ surface in the equatorial Pacific Ocean $\left(12^{\circ} \mathrm{S}\right)$, documenting an additional control on [Si] and $\delta^{30} \mathrm{Si}$ here, as discussed in Sect. 5.2.

strong northward deepening of this gradient can be quantitatively illustrated by considering the depth at which seawater $\delta^{30} \mathrm{Si}$ values nominally exceed an elevated value of $+1.6 \%$ : this surface deepens from just $175 \mathrm{~m}$ at $62^{\circ} \mathrm{S}$ to a maximum of $858 \mathrm{~m}$ at $37.5^{\circ} \mathrm{S}$ before shoaling northwards, reaching $\sim 150 \mathrm{~m}$ at $12^{\circ} \mathrm{S}$. As Fig. 4 shows, the depth variation of this surface closely follows two surfaces associated with AAIW spreading north of $50^{\circ} \mathrm{S}$ : the $\gamma^{\mathrm{n}}=27.25 \mathrm{~kg} \mathrm{~m}^{-3}$ surface (Tsuchiya and Talley, 1998) and the deepest surface with negative values of the tracer $\mathrm{Si}^{*}\left(=[\mathrm{Si}]-\left[\mathrm{NO}_{3}\right]\right.$; Sarmiento et al., 2004). This close similarity implies a strong isopycnal control on the ${ }^{30} \mathrm{Si}$ distribution, as expected from Fig. 3.

Accounting for the changes in isopycnal depths across the latitudinal range of this study by using $\gamma^{\mathrm{n}}$ as the vertical axis (Fig. 5) emphasizes the coherence in the $\delta^{30} \mathrm{Si}$ distribution along isopycnals. Profiles in the deeper water column $\left(\gamma^{\mathrm{n}} \geq 27.7 \mathrm{~kg} \mathrm{~m}^{-3}\right)$ show that $\delta^{30} \mathrm{Si}$ values do not change significantly at depth (Fig. 5c), even though [Si] increases northwards along isopycnals by as much as $63 \%$ (Fig. 5d). In the upper water column, however, both marked meridional differences as well as clear structure are seen in the $\delta^{30} \mathrm{Si}$ distribution. The summer and winter mixed layers (stars in Fig. 5) of the southernmost stations $\left(62^{\circ}\right.$ and $\left.58^{\circ} \mathrm{S}\right)$ show high $\delta^{30} \mathrm{Si}$ values $(+1.8 \%$ to $+3.2 \%$ ) at relatively high densities (up to $\gamma^{\mathrm{n}}=27.5 \mathrm{~kg} \mathrm{~m}^{-3}$ ) that outcrop at these high latitudes. In the subsurface water column below the depth of the winter mixed layer, all stations from $62^{\circ} \mathrm{S}$ to $37.5^{\circ} \mathrm{S}$ exhibit very similar $\delta^{30} \mathrm{Si}-\gamma^{\mathrm{n}}$ relationships, increasing to $\delta^{30} \mathrm{Si}$ values of around $+1.8 \%$ at $\gamma^{\mathrm{n}} \approx 27.15 \mathrm{~kg} \mathrm{~m}^{-3}$, the level of SAMW. A completely different $\delta^{30} \mathrm{Si}-\gamma^{\mathrm{n}}$ relationship is seen at $12^{\circ} \mathrm{S}$, where $\delta^{30} \mathrm{Si}$ values remain con- stant around a low value of $+1.4 \%$ up to densities as low as $\gamma^{\mathrm{n}}=26.6 \mathrm{~kg} \mathrm{~m}^{-3}$.

The only non-monotonic $\delta^{30} \mathrm{Si}-\gamma^{\mathrm{n}}$ relationship is observed at $26^{\circ} \mathrm{S}$, which remains similar to the more southerly stations up to $\gamma^{\mathrm{n}} \approx 27.15 \mathrm{~kg} \mathrm{~m}^{-3}$, above which it appears to follow the relationship defined by the equatorial water column at $12^{\circ} \mathrm{S}$. This transitional nature is also reflected in the mesopelagic [Si] distribution (Fig. 5b, and Figs. S1 and S2 in the Supplement): for $\gamma^{\mathrm{n}} \geq 27.15 \mathrm{~kg} \mathrm{~m}^{-3}$, Si concentrations at $26^{\circ} \mathrm{S}$ are very similar to those further south, which are essentially invariant along isopycnals. Above this level, the water column at $26^{\circ} \mathrm{S}$ exhibits elevated [Si] over a range centered at $\gamma^{\mathrm{n}} \approx 26.75 \mathrm{~kg} \mathrm{~m}^{-3}$, the level at which a low- $\left[\mathrm{O}_{2}\right]$ equatorial signal propagates southwards (Sect. 3). Silicon concentrations along this isopycnal increase linearly with salinity towards the north (Fig. S2), reflecting the spreading of saline, $\mathrm{Si}$-rich and $\mathrm{O}_{2}$-poor equatorial waters into the subtropics at this density level.

\section{Discussion}

We first discuss the $\delta^{30} \mathrm{Si}$ distribution in the upper ocean, analyzing the systematics of $\delta^{30} \mathrm{Si}$ values at the high-latitude surface before tracing their subsurface evolution in the mesopelagic subtropical (Sect. 5.1) and equatorial (Sect. 5.2) South Pacific. We then discuss the deep Pacific $\delta^{30}$ Si distribution (Sect. 5.3), and identify key questions that will require more detailed study in the future (Sect. 5.4).

\subsection{High-latitude control on subtropical $\delta^{30} \mathrm{Si}$ distribution}

Values of $\delta^{30} \mathrm{Si}$ are high in the surface mixed layers of the high-latitude stations at $62^{\circ} \mathrm{S}$ and $58^{\circ} \mathrm{S}$, as well as in the nutricline just below the base of the mixed layer at $58^{\circ} \mathrm{S}$ and $50^{\circ} \mathrm{S}$. These elevated $\delta^{30} \mathrm{Si}$ values are the direct result of $\mathrm{Si}$ isotope fractionation during uptake of $\mathrm{Si}$ by diatoms; satellite-based estimates (MODIS Aqua; Fig. S3) indicate that the highest chlorophyll $a$ concentrations were attained about 6-8 weeks before the Ronald H. Brown arrived at high latitudes in late summer (February 2008). The extremely high $\delta^{30} \mathrm{Si}$ values of up to $+3.2 \%$ o confirm previous observations that diatom $\mathrm{Si}$ isotope fractionation in the surface Southern Ocean produces highly elevated $\delta^{30} \mathrm{Si}$ values at relatively high [Si] of 3-6 $\mu \mathrm{M}$ (e.g., Varela et al., 2004; Fripiat et al., 2011a, Fig. S4). Late summer mixed layers at high latitudes thus represent a considerable inventory of high- $\delta^{30} \mathrm{Si}$ silicic acid, such that they have the potential to influence seawater $\delta^{30} \mathrm{Si}$ values when mixed with other water masses by physical processes. Below, we show that this influence is clearly visible, and trace the introduction of the surface nutrient utilization signal into the ocean interior over a number of steps. 

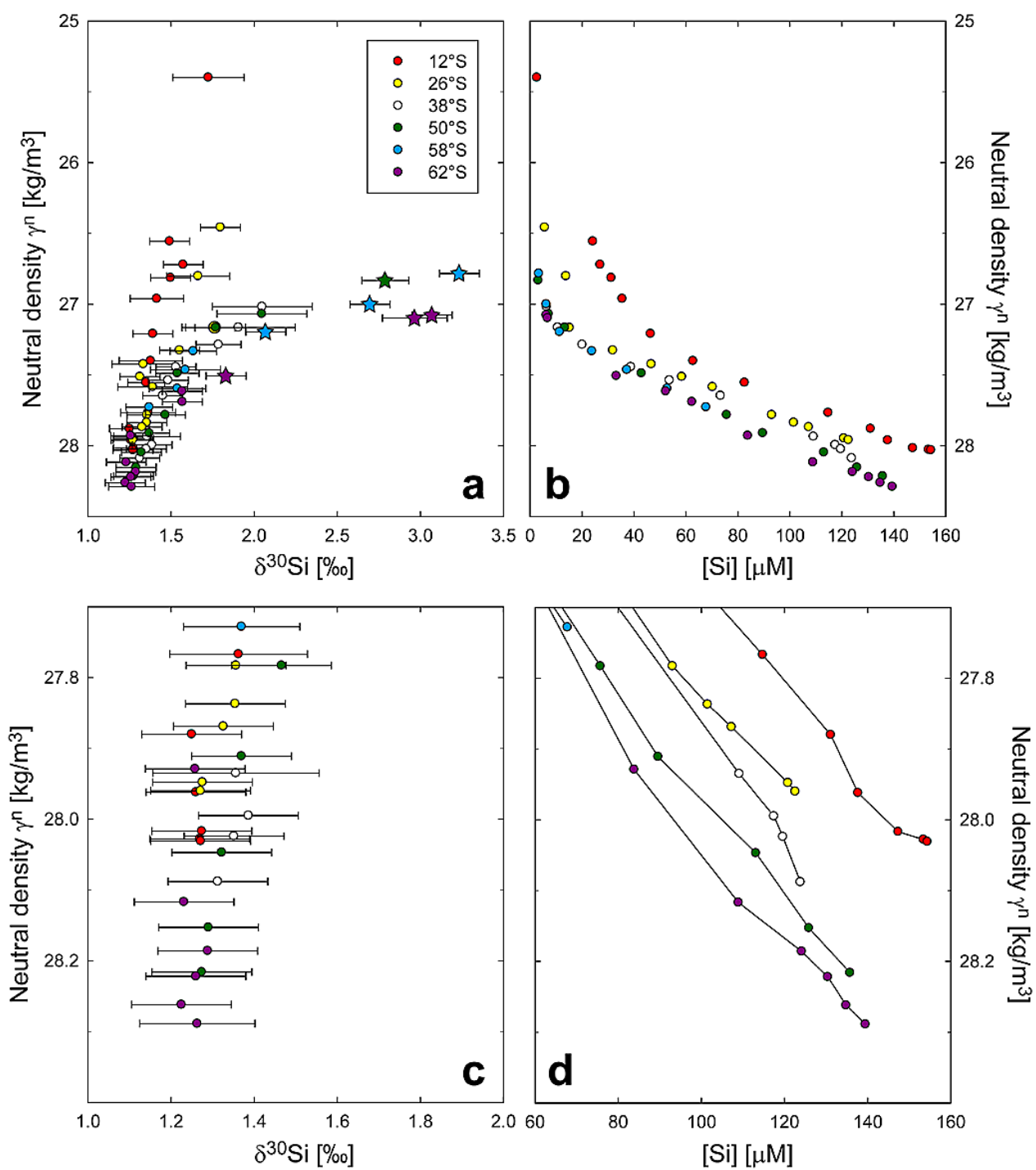

Fig. 5. Profiles of $\delta^{30} \mathrm{Si}$ values (a and $\left.\mathbf{c}\right)$ and [Si] (b and $\left.\mathbf{d}\right)$ versus neutral density $\left(\gamma^{\mathrm{n}}\right)$ over the entire sampled water column (upper panels) and below $\gamma^{\mathrm{n}}=27.7 \mathrm{~kg} \mathrm{~m}^{-3}$. Stars represent high-latitude summer and winter mixed layers (winter mixed layers were identified by the temperature minimum $\left(62^{\circ} \mathrm{S}\right)$ or potential vorticity minimum $\left.\left(58^{\circ} \mathrm{S}\right)\right)$. Note the different $\mathrm{x}$-axis scales in the upper and lower panels.

\subsubsection{Deep winter convection}

At high latitudes, strong cooling of surface water in winter leads to destabilization of the water column and convection to depths of $>400 \mathrm{~m}$ (e.g., Dong et al., 2008), forming a thick winter mixed layer with uniform properties. Analysis of the $\delta^{30} \mathrm{Si}$ systematics of the near-surface water column at the two southernmost stations shows that the high $\delta^{30} \mathrm{Si}$ values produced in the surface during summer are communicated to the winter mixed layer during deep winter convection: a mixing diagram (Fig. 6) shows that the winter mixed layers lie approximately on a mixing line between the base of the summer mixed layer and the deeper water column. We can thus determine the contribution of the late summer surface to the winter mixed layer Si inventory using a simple mixing relationship:

$X_{\mathrm{SS}}=\frac{\delta^{30} \mathrm{Si}_{\mathrm{WML}}-\delta^{30} \mathrm{Si}_{\text {deep }}}{\delta^{30} \mathrm{Si}_{\mathrm{SS}}-\delta^{30} \mathrm{Si}_{\text {deep }}}$

where SS refers to the later summer surface, WML to the winter mixed layer and deep to the water column immediately below the WML, and $X_{\mathrm{SS}}$ is the proportion of $\mathrm{Si}$ in the WML supplied by the late summer surface waters. Solving Eq. 2 for the high-latitude stations indicates that the surface waters contribute only about $20-25 \%$ of the $\mathrm{Si}$ within the winter mixed layer, very similar to analogous estimates by Fripiat et al. $(2011 \mathrm{a}, \mathrm{b})$ in the Atlantic and Indian sectors. This low Si contribution from the summer mixed layer is due to the entrainment of Si-replete subsurface waters by the $\mathrm{Si}$ depleted surface waters during convection. As a result, the 


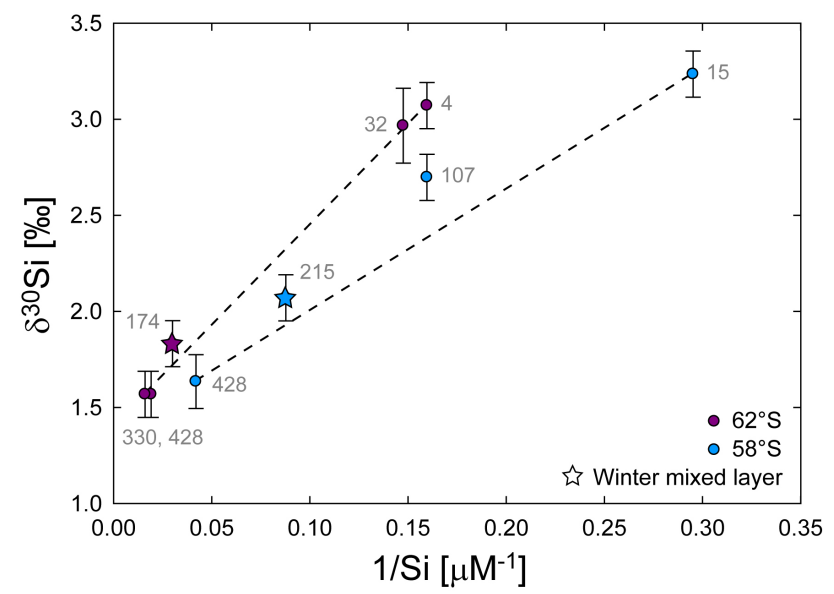

Fig. 6. A mixing diagram of $\delta^{30} \mathrm{Si}$ versus $1 /[\mathrm{Si}]$ for samples in the near-surface polar ocean. Stars represent the winter mixed layer (identified by the temperature minimum $\left(62^{\circ} \mathrm{S}\right)$ or potential vorticity minimum $\left(58^{\circ} \mathrm{S}\right)$ ). Dotted lines are drawn between the shallowest and deepest samples (depths indicated by gray numbers, in meters) to guide the eye; note that the winter mixed layer at $58^{\circ} \mathrm{S}$ appears to be more consistent with mixing between the base of the mixed layer and the deeper water column, which highlights that the real system is more spatially complex than assumed in this simple view.

$\delta^{30} \mathrm{Si}$ signal of utilization is strongly attenuated by convection, from values over $+3 \%$ o to values around $+2 \%$, but the influence of the high- $\delta^{30} \mathrm{Si}$ signal continues to be clearly expressed in the winter mixed layer, as similarly observed by Fripiat et al. (2011a).

In order for the high-latitude winter mixed layer to preserve a $\delta^{30} \mathrm{Si}$ value higher than that of the upwelling source of $\mathrm{Si}$ to the surface, mass balance demands a low- $\delta^{30} \mathrm{Si}$ flux across the base of the winter mixed layer. The elevated $\delta^{30} \mathrm{Si}$ values of the winter mixed layer hence imply that a significant portion of the opal produced in the surface ocean is exported past the depth of deepest convection, and that this opal has a low $\delta^{30} \mathrm{Si}$ value. Thus, the effects of a strongly expressed isotope effect of Si utilization, efficient particulate export, and buoyancy-driven mixing combine over the annual cycle to fractionate $\mathrm{Si}$ isotopes between the deeper Southern Ocean and the annually accessible surface. This is the first step in the production of a high $\delta^{30} \mathrm{Si}$ value in the ocean interior, as discussed below.

\subsubsection{Subduction of mode and intermediate waters}

The winter convection that leads to deep mixed layers in the Subantarctic Zone is the first step in the formation of SAMW, of which southeast Pacific AAIW is the densest type (McCartney, 1977; Hanawa and Talley, 2001). These water masses are subducted into the ocean interior from the winter outcrops of their density surfaces $\left(56^{\circ}-61^{\circ} \mathrm{S}\right.$ at $103^{\circ} \mathrm{W}$; Antonov et al., 2010; Locarnini et al., 2010) by the combined effects of lateral induction, Ekman pumping, and mesoscale eddy-induced advection (Karstensen and Quadfasel, 2002; Sallée et al., 2010). When they subduct, the water masses introduce the properties of the Subantarctic winter mixed layer, such as high concentrations of oxygen and anthropogenic chlorofluorocarbons (CFCs; Fine et al., 2001) and negative $\mathrm{Si}^{*}$ values (Sarmiento et al., 2004), into the basal levels of the permanent thermocline (Stommel, 1979). This same process also necessarily subducts the high $\delta^{30} \mathrm{Si}$ values of the winter mixed layer into the ocean interior. As the $\delta^{30} \mathrm{Si}-\gamma^{\mathrm{n}}$ relationship documents (Fig. 5), these high values are not destroyed by mixing downstream, but rather conserved exceptionally well along the flow path of SAMW and AAIW in the subtropical interior. For all samples within the SAMWAAIW density range of $\gamma^{\mathrm{n}}=27.15-27.3 \mathrm{~kg} \mathrm{~m}^{-3}$, the $\delta^{30} \mathrm{Si}$ values of all stations south of $12^{\circ} \mathrm{S}$ are essentially identical to each other (and to the winter mixed layer at $58^{\circ} \mathrm{S}$ ). As Fig. 3 shows, there is a striking correspondence of high subsurface $\delta^{30} \mathrm{Si}$ values with the tongue of low salinity and negative $\mathrm{Si}^{*}$ that traces SAMW/AAIW. The close association of these well-ventilated waters with high $\delta^{30} \mathrm{Si}$ values in the subsurface is further illustrated by the correlation between high $\delta^{30} \mathrm{Si}$ values and significant concentrations of anthropogenic CFC-11 in subsurface waters (Fig. S5).

The broad latitudinal span of our data thus reveals that the high- $\delta^{30} \mathrm{Si}$ signal of SAMW/AAIW, a result of high-latitude nutrient dynamics, is preserved far to the north as these waters spread into the subtropical ocean interior. The strong isopycnal coherence of $\delta^{30} \mathrm{Si}$ values unequivocally documents the importance of these water masses in supplying $\mathrm{Si}$ to the low-latitude thermocline, as postulated by Sarmiento et al. (2004). Furthermore, the degree to which $\delta^{30} \mathrm{Si}$ values are conserved far into the subtropical Pacific Ocean implies that the preformed component of $\mathrm{Si}$, incorporated into SAMW/AAIW during subduction, remains dominant in the well-ventilated subtropical gyre - and thus that opal dissolution plays an insignificant role in determining the Si distribution here. This picture changes dramatically in the equatorial regime north of $20^{\circ} \mathrm{S}$, and it is to this section of the dataset that we now turn.

\subsection{Low $\delta^{30} \mathrm{Si}$ in the mesopelagic equatorial Pacific}

The $\delta^{30} \mathrm{Si}$ distribution at $12^{\circ} \mathrm{S}$ is completely different from that at the more southerly stations, with uniformly low values throughout the upper water column, as similarly observed by Beucher et al. (2008) near the Equator $\left(3^{\circ} \mathrm{S}-4^{\circ} \mathrm{N}\right)$. The high$\delta^{30} \mathrm{Si}$ signature of SAMW and AAIW, which is strongly conserved further south, is lost in the equatorial Pacific. In the following, we attempt to identify the origin of this difference, which requires consideration of the circulation and nature of biogeochemical cycling in the equatorial Pacific Ocean.

Tracer distributions (Fig. 2) as well as $\theta-S$ relationships (Fig. S6) show that the mesopelagic water column at $12^{\circ} \mathrm{S}$ is markedly different from that within the subtropical gyre: it is 

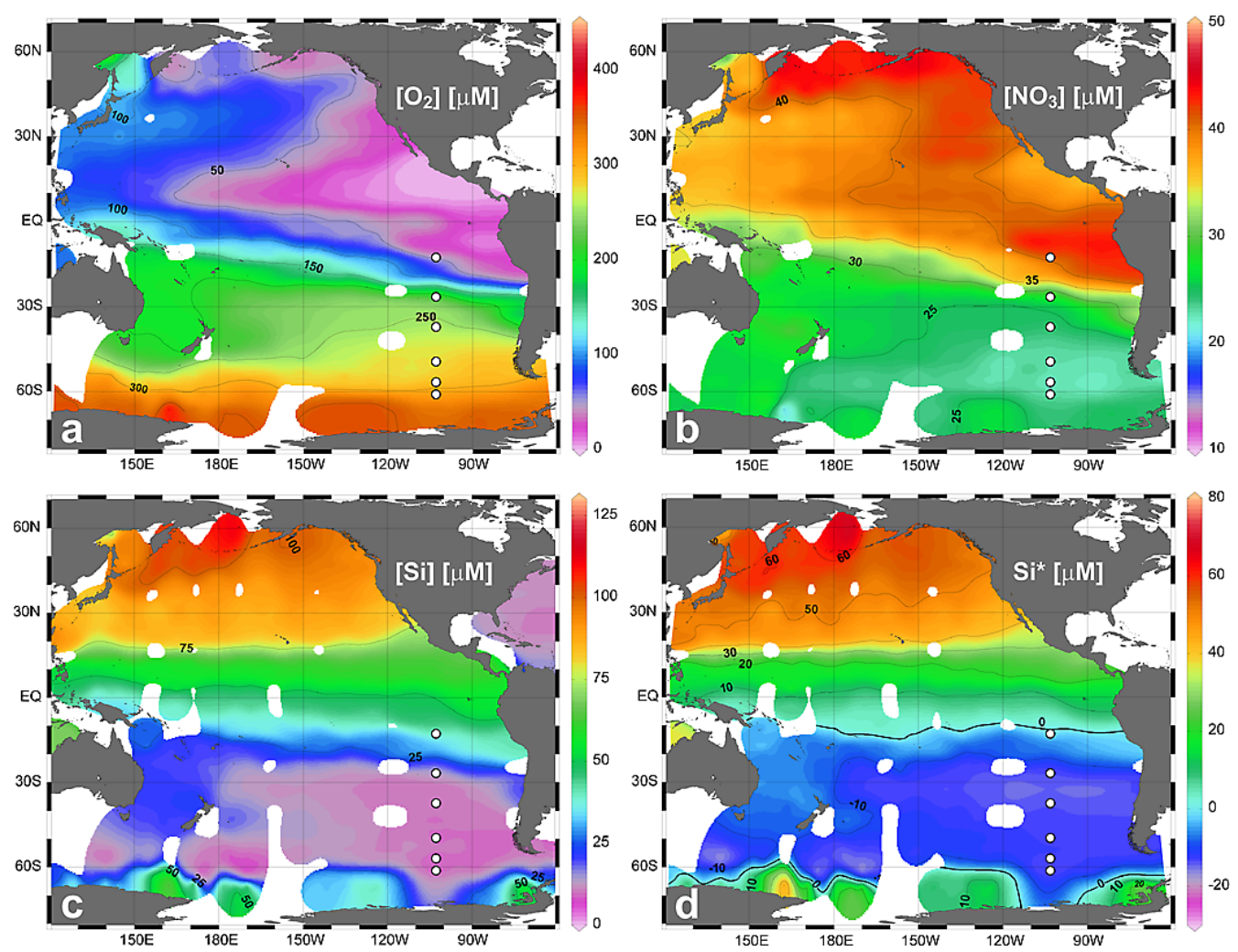

Fig. 7. Concentrations of biogeochemical tracers along the $\gamma^{\mathrm{n}}=27.15 \mathrm{~kg} \mathrm{~m}^{-3}$ surface that corresponds to SAMW in the South Pacific Ocean. White circles denote sampling locations. Data are from the eWOCE database (Schlitzer, 2000). Note that values of $\mathrm{Si}^{*}$ in the Eastern Pacific Ocean are affected by denitrification in the suboxic water column.

more saline, poorer in oxygen and richer in nutrients. These features are the result of a number of processes. Thermocline and intermediate waters of the subtropical gyre transit to the equatorial regime via a northward western boundary undercurrent in the Western Pacific. The downward mixing of upper, more saline waters in the undercurrent is the most likely cause of the observed salinity increase (Tsuchiya and Talley, 1996), since AAIW already exhibits the typical salinity and density of its equatorial type $\left(S=34.5, \gamma^{\mathrm{n}}=27.45 \mathrm{~kg} \mathrm{~m}^{-3}\right)$ when it reaches the western equatorial Pacific (Tsuchiya, 1991). Within the equatorial system, conservative parameters show little zonal variability on mesopelagic isopycnals. In stark contrast to this, biogeochemical tracers such as oxygen and nitrate show strong zonal isopycnal gradients, with the Eastern Pacific being nitrate-richer and oxygen-poorer than the west (Fig. 7a and b); indeed, the Eastern Pacific hosts the ocean's most extensive OMZs. The oxygen depletion and nitrate enrichment are the result of a combination of sluggish ventilation, strongly zonal flow, and the remineralization of organic matter that leads to a high oxygen demand (e.g., Karstensen et al., 2008). These processes lead to the buildup of a large pool of remineralized nutrients in the eastern subsurface (e.g., Toggweiler and Carson, 1995).
Interestingly, $\mathrm{Si}$ is an exception to the general rule of strong zonal concentration gradients (Fig. 7c): Si concentrations primarily show a strong meridional gradient, with no zonal component along the Equator, while a mild zonal gradient is associated with the Peruvian coastal upwelling centered at about $10^{\circ} \mathrm{S}$. These two gradients reflect two different processes that control the Si distribution in the mesopelagic equatorial Pacific. The meridional gradient is the result of the very marked difference in the Si content of basal thermocline waters of South and North Pacific origin. This disparity is displayed in the distribution of the tracer $\mathrm{Si}^{*}$, which increases from negative values in the south (representing a Si deficit) to highly positive values in the north (Fig. 7d; Sarmiento et al., 2004). At the depth level of the Equatorial Undercurrent (EUC) that is fed by both northern and southern sources (Tsuchiya et al., 1989; Toggweiler et al., 1991), Dugdale et al. (2002) have shown that the disparate $\mathrm{Si}$ content of northern and southern waters results in waters of North Pacific origin contributing disproportionately to the $\mathrm{Si}$ budget, supplying $70 \%$ of Si in the EUC. This lateral influence of the Si-rich North Pacific is reflected in the meridional $\mathrm{Si}^{*}$ and $[\mathrm{Si}]$ gradients across the equatorial Pacific Ocean. 
In addition to this meridional gradient, there is also a zonal [Si] gradient south of the Equator, associated with the Peruvian coastal upwelling. This gradient can be viewed as the result of an additional enrichment of $\mathrm{Si}$ on isopycnals towards the east, over and above the enrichment caused by the incorporation of a Si-rich North Pacific component. Such an enrichment is analogous to the accumulation of remineralized nitrate documented by the model of Toggweiler and Carson (1995), suggesting that there is a significant contribution of remineralized $\mathrm{Si}$ at the eastern margin of the equatorial $\mathrm{Pa}-$ cific subsurface, which may find its surface expression in the tongue of high surface [Si] $(6-8 \mu \mathrm{M})$ extending westwards from the Peruvian coast (Garcia et al., 2010b).

Thus, the $>100 \%$ increase in [Si] (from $21 \mu \mathrm{M}$ to $46 \mu \mathrm{M}$ ) at SAMW densities $\left(\gamma^{\mathrm{n}} \approx 27.15 \mathrm{~kg} \mathrm{~m}^{-3}\right)$ between $26^{\circ} \mathrm{S}$ and $12^{\circ} \mathrm{S}$ can be viewed as the combined result of lateral input of Si from the North Pacific, and the accumulation of remineralized Si within the shadow zone of the eastern equatorial Pacific. A simple isotope mass balance calculation indicates that, to explain the observed decrease in $\delta^{30} \mathrm{Si}$ values at the density level of SAMW (from $+1.76 \%$ o to $+1.38 \%$ ) between $26^{\circ} \mathrm{S}$ and $12^{\circ} \mathrm{S}$, these two processes would need to contribute $\mathrm{Si}$ with a $\delta^{30} \mathrm{Si}$ value of $+1.2 \%$, a value that is not abnormal for either seawater or diatom opal. An estimate of the value for the North Pacific source is hampered by the paucity of data. However, at $24^{\circ} \mathrm{N}$ and $170^{\circ} \mathrm{E}$, Reynolds et al. (2006) reported $\delta^{30} \mathrm{Si}$ values of $+1.31 \%$ and $+1.32 \%$ at depths that bracket the $\gamma^{\mathrm{n}}=27.15 \mathrm{~kg} \mathrm{~m}^{-3}$ surface $(600 \mathrm{~m}$ and $900 \mathrm{~m})$, indicating that the input of North Pacific Si would be expected to lower $\delta^{30} \mathrm{Si}$ values in the mesopelagic equatorial Pacific. The dissolution of opal produced in the Peruvian coastal upwelling may also add $\mathrm{Si}$ with a low $\delta^{30} \mathrm{Si}$ value to subsurface waters, by a mechanism analogous to that we have seen at work in another upwelling region, the Southern Ocean. In the Peruvian upwelling, Si utilization is below $100 \%$, as documented by elevated [Si] at the surface (Garcia et al., 2010b). As a result, opal exported from the surface will tend to add a low $\delta^{30} \mathrm{Si}$ value to the subsurface when it dissolves. Thus, subsurface waters may accumulate a pool of $\mathrm{Si}$ with lower $\delta^{30} \mathrm{Si}$ values during their long residence in the shadow zone of the equatorial Pacific.

The observed differences in the $\delta^{30} \mathrm{Si}$ distribution in the mesopelagic subtropical and equatorial Pacific are thus due to the fact that (a) the equatorial Pacific is one of the few ocean regions where the mesopelagic $\mathrm{Si}$ inventory is not dominantly supplied by waters of Southern Ocean origin (Dugdale et al., 2002; Sarmiento et al., 2004) and/or that (b) the remineralized component of $\mathrm{Si}$ appears to be higher in the southeast equatorial region, associated with the Peruvian coastal upwelling. In other words, the subsurface $\delta^{30} \mathrm{Si}$ distribution traces the cycling of Si within the upper ocean, but records the combination of a preformed signal and a remineralized signal that is integrated over the entire circulation history of the water mass in which the dissolved Si pool is transported, and must be interpreted as such. Although the conflation of source and cycling signals in the equatorial Pacific means that the effect of dissolution cannot be robustly separated from the signal of $\mathrm{Si}$ addition from the North Pacific, it appears that the sluggish circulation of the eastern equatorial Pacific, which contains some of the most poorly ventilated waters of the global ocean (Karstensen et al., 2008; Garcia et al., 2010a), allows such a remineralization signal to be recorded, whilst within well-ventilated subtropical waters, the $\delta^{30} \mathrm{Si}$ signal is dominated by the preformed component of $\mathrm{Si}$ introduced into the interior by SAMW/AAIW.

The interaction of waters from these two regimes and its influence on the thermocline $\delta^{30} \mathrm{Si}$ distribution is nicely illustrated by a detail of the $\delta^{30} \mathrm{Si}$ profile at $26^{\circ} \mathrm{S}$ : this subtropical station exhibits an isopycnal Si-enrichment around $\gamma^{\mathrm{n}}=$ $26.75 \mathrm{~kg} \mathrm{~m}^{-3}$ that is associated with the southward spreading of $\mathrm{O}_{2}$-poor equatorial waters into the subtropics (Sect. 3 and Supplement). The $\delta^{30} \mathrm{Si}$ distribution appears to reflect this interleaving of subtropical and tropical waters (Figs. 3 and 5a): a tongue of high "subtropical" ${ }^{30} \mathrm{Si}$ values extends below the southward-spreading $\mathrm{O}_{2}$ minimum, which exhibits low "equatorial" $\delta^{30} \mathrm{Si}$ values that are essentially identical to those observed in the Peru-Chile Undercurrent (Ehlert et al., 2012), a potential conduit of equatorial waters into the subtropics (Sect. 3). This pattern provides further evidence of the strong isopycnal control on $\delta^{30} \mathrm{Si}$ values in the oceanic thermocline.

\subsection{Evidence for widespread deep $\delta^{30} \mathrm{Si}$ uniformity}

In contrast to the rich structure observed in the upper ocean, the deep waters analyzed in this study exhibit remarkable homogeneity in $\delta^{30} \mathrm{Si}$ values. In the Southern Ocean, $\delta^{30} \mathrm{Si}$ values average $+1.25 \pm 0.05 \%$ o $\left(2 \sigma_{\mathrm{SD}}\right)$ over the entire deep water column. This value is indistinguishable from three other geographically widespread observations of deep Southern Ocean $\delta^{30} \mathrm{Si}$ : values of $+1.21 \pm 0.06 \%$ in $\mathrm{CDW}$ from Drake Passage (de Souza et al., 2012), $+1.22 \pm 0.12 \%$ in the deep Southern Ocean south of Australia $\left(\sim 140^{\circ} \mathrm{E}\right.$; Cardinal et al., 2005), and $+1.26 \pm 0.13 \%$ o that we observe in Southern Ocean deep waters in the Indo-Atlantic sector at $30^{\circ} \mathrm{E}$ (Supplementary Table 1). Although based on only 6 Pacific data points, the exceptionally close similarity of the $\delta^{30} \mathrm{Si}$ values of CDW in the far eastern Pacific and Australian sectors contradicts the recent prediction, by Fripiat et al. (2011a) of a $\delta^{30} \mathrm{Si}$ gradient in CDW between these two sectors. This prediction was based on the statistically significant $\delta^{30} \mathrm{Si}$ offset of $\sim 0.2 \%$ o that Fripiat et al. (2011a) observed between their Atlantic-sector CDW data and the Australian-sector data of Cardinal et al. (2005) (Fig. S7). They suggested that a higher $\delta^{30} \mathrm{Si}$ value in the Atlantic sector may result from the influence of NADW, which transports $\mathrm{Si}$ with a high $\delta^{30} \mathrm{Si}$ value (de Souza et al., 2012). However, such an influence is not to be expected, given the low Si mass flux associated with NADW. Mixing calculations based on the quasi-conservative tracer $\mathrm{PO}_{4}^{*}$ (Broecker et al., 1991, see Supplement) indicate 
that the influence of freshly ventilated NADW on CDW $\delta^{30} \mathrm{Si}$ values should in fact be restricted to around $0.05 \%$, below analytical resolution (Fig. S8). Indeed, our data from the Indo-Atlantic sector, which sample the salinity maximum of NADW as it passes south of Africa, do not reveal any evidence for a significant NADW influence on deep water $\delta^{30} \mathrm{Si}$ values there (Fig. S8, Supplement Table 1). Thus, the $\delta^{30} \mathrm{Si}$ difference observed by Fripiat et al. (2011a) remains surprising and unexplained. On the other hand, whilst we reiterate that the geographic distribution of observations is still quite limited, and the number of data points small, the fact remains that numerous geographically widespread observations of $\delta^{30} \mathrm{Si}$ in the deep Southern Ocean (including this study's data from Southern Ocean sectors as far from each other as the Indo-Atlantic and the eastern Pacific) indicate that the $\delta^{30} \mathrm{Si}$ value of Circumpolar Deep Water is zonally homogeneous at the sub- $0.1 \%$ level (Fig. S7). Future work to improve the spatial distribution of $\delta^{30} \mathrm{Si}$ observations in the deep Southern Ocean will help resolve whether this is indeed the case.

In addition to the tantalizing evidence for large-scale $\delta^{30} \mathrm{Si}$ homogeneity in CDW, the statistical tests detailed in Sect. 4 indicate that significance cannot be attributed to the small nominal $\delta^{30} \mathrm{Si}$ variations observed further north in the deep South Pacific. Our deep Pacific data document a high degree of $\delta^{30} \mathrm{Si}$ homogeneity (Fig. 5c), with no significant $\delta^{30} \mathrm{Si}$ differences for deep waters with $\gamma^{\mathrm{n}}>27.7 \mathrm{~kg} \mathrm{~m}^{-3}$, whilst $\delta^{30} \mathrm{Si}$ values in lighter waters begin to increase (Fig. 5a). Importantly, this homogeneity extends to deep waters from the northern Bauer Basin $\left(12^{\circ} \mathrm{S}\right)$ where other water properties document a North Pacific origin. Although uncertainties regarding the deep North Pacific $\delta^{30} \mathrm{Si}$ distribution (discussed in Sect. 5.4) make firm conclusions difficult, we would argue that this marked constancy may reflect a fundamental property of the oceanic $\delta^{30} \mathrm{Si}$ distribution. The density level below which no significant $\delta^{30} \mathrm{Si}$ variation occurs corresponds closely to the density that separates the upper and lower cells of the overturning circulation in the inverse model of Lumpkin and Speer $\left(2007, \gamma^{\mathrm{n}}=27.6 \mathrm{~kg} \mathrm{~m}^{-3}\right)$. This separation reflects the fact that the predominant source of deep waters to the Pacific is CDW from the deep Southern Ocean, the lower limb of the MOC (Johnson, 2008). If the $\delta^{30} \mathrm{Si}$ values of these deep waters remain constant over their multicentennial sojourn in the deep Pacific (Matsumoto, 2007), the implication is that the accumulation of Si from the dissolution of sinking diatom opal produces no significant $\delta^{30} \mathrm{Si}$ signal in the deep Pacific Ocean. This would, in turn, indicate that the production of significant deep water $\delta^{30} \mathrm{Si}$ variation requires the presence of a $\delta^{30} \mathrm{Si}$ signal in the preformed component, analogous to the case for both SAMW/AAIW (Sect. 5.1) and NADW (de Souza et al., 2012). However, as we detail below, there are a number of inconsistencies in the deep Pacific $\delta^{30} \mathrm{Si}$ distribution that need to be resolved before this conclusion can be robustly made.

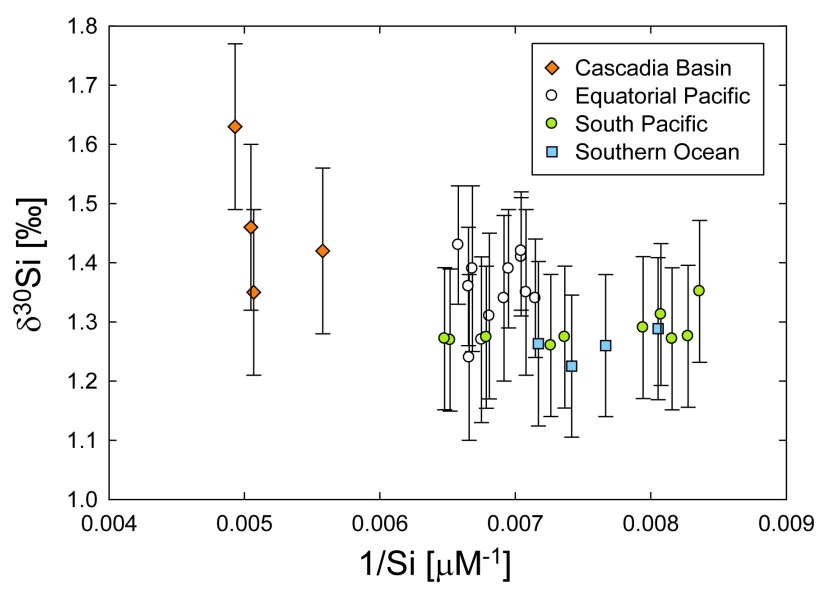

Fig. 8. A mixing diagram of $\delta^{30} \mathrm{Si}$ versus $1 /[\mathrm{Si}]$ showing deep waters from the Pacific sector of the Southern Ocean to the Cascadia Basin in the North Pacific $\left(47^{\circ} N\right)$. All deep water $\left(\gamma^{n} \geq\right.$ $27.93 \mathrm{~kg} \mathrm{~m}^{-3}$ ) samples with [Si] equal to or higher than that of the deep inflow of CDW into the Pacific Ocean $(120 \mu \mathrm{M}$; e.g., Warren, 1973) are included. Cascadia Basin and equatorial Pacific data are from Beucher et al. $(2008,2011)$; error bars correspond to external reproducibilities reported by the authors. From the Equator southwards, any $\delta^{30} \mathrm{Si}$ variation is clearly at the limit of analytical resolution, especially considering that $\delta^{30} \mathrm{Si}$ offsets on the order of $\pm 0.1 \%$ o between laboratories are possible (Reynolds et al., 2007).

\subsection{The deep Pacific $\delta^{30} \mathrm{Si}$ conundrum}

A wide range of $\delta^{30} \mathrm{Si}$ values have been reported from the deep North Pacific Ocean. De La Rocha et al. (2000) and Reynolds et al. (2006) have reported low $\delta^{30} \mathrm{Si}$ values of around $+0.8 \%$ in deep waters of the Northwestern Pacific $\left(24^{\circ}-45^{\circ} \mathrm{N}, 150^{\circ}-170^{\circ} \mathrm{W}\right)$, whilst Beucher et al. (2008) observed values as high as $+1.63 \%$ in the extremely Si-rich $(\sim 200 \mu \mathrm{M})$ waters of the Cascadia Basin in the Northeastern Pacific. Both De La Rocha et al. (2000) and Reynolds et al. (2006) interpreted their results as documenting the dissolution of low $-\delta^{30} \mathrm{Si}$ opal in the deep ocean, whilst Beucher et al. (2008) conversely inferred that the high $\delta^{30} \mathrm{Si}$ values they observed result from the dissolution of opal with a higher $\delta^{30} \mathrm{Si}$ value than Pacific deep waters. These mutually contradictory conclusions highlight the ambiguity of the extant $\delta^{30} \mathrm{Si}$ data, and also contrast with our inference of essentially invariant $\delta^{30} \mathrm{Si}$ values in the deep Pacific (Sect. 5.3).

Further uncertainty exists regarding the variability or constancy of deep Pacific $\delta^{30} \mathrm{Si}$ values at lower latitudes. Beucher et al. (2008) observed a $\delta^{30} \mathrm{Si}$ value of $+1.32 \pm$ $0.11 \%$ o $(n=6)$ in the equatorial Pacific $\left(1^{\circ} \mathrm{N}-3^{\circ} \mathrm{S}, 110^{\circ} \mathrm{W}\right)$, very similar to the average deep South Pacific $\delta^{30} \mathrm{Si}$ value of $+1.30 \pm 0.08 \%$ reported here. However, Beucher et al. (2008) attributed significance to the fact that the $\delta^{30} \mathrm{Si}$ value they observed is nominally higher than that reported for CDW by De La Rocha et al. $(2000,+1.1 \pm 0.2 \%$ ) and Cardinal et al. $(2005,+1.22 \pm 0.12 \%$ ). They inferred that this 
difference results from mixing between $\mathrm{CDW}$ and high- $\delta^{30} \mathrm{Si}$ waters of the deep Si plume that emanates from the Northeastern Pacific (e.g., Talley and Joyce, 1992). However, such an inference is not upheld by the isotope systematics of a compilation of equatorial and Southern Pacific deep water data (this study; Beucher et al., 2008, 2011). In a mixing diagram (Fig. 8), these data do not display any systematic $\delta^{30} \mathrm{Si}$ variability such as would be expected from mixing (cf. the deep Atlantic $\delta^{30} \mathrm{Si}$ distribution; de Souza et al., 2012) - in fact, within analytical uncertainty, no variability in the deep Pacific from the Equator southwards is apparent. The largescale influence of high- $\delta^{30} \mathrm{Si}$ Northeastern Pacific waters on the low-latitude open Pacific $\delta^{30} \mathrm{Si}$ distribution postulated by Beucher et al. (2008) thus remains questionable.

The clarity of the situation is not improved by the fact that the pioneering data of De La Rocha et al. (2000) show some surprising features, such as mid-depth $\delta^{30} \mathrm{Si}$ variations of as much as $0.5 \%$ at a single North Pacific station, as well as values as low as $+0.8 \%$ at $300 \mathrm{~m}$ water depth at $24^{\circ} \mathrm{N}$. Considering the range of subsurface seawater $\delta^{30} \mathrm{Si}$ variation documented by the literature published since that first study (Cardinal et al., 2005; Reynolds et al., 2006; Beucher et al., 2008, 2011; Cavagna et al., 2011; Fripiat et al., 2011a,b; de Souza et al., 2012, and this study), these features appear anomalous, and cast some doubt on the accuracy of the data of De La Rocha et al. (2000), thus adding a further layer of uncertainty to the deep Pacific $\delta^{30} \mathrm{Si}$ distribution.

Clearly, there are numerous questions regarding the deep Pacific $\delta^{30} \mathrm{Si}$ distribution that remain unanswered. Tackling them will require a systematic regional-scale North Pacific $\delta^{30} \mathrm{Si}$ survey that encompasses the Northeastern Pacific deep Si plume. In the absence of this, a conclusive characterization of the deep Pacific $\delta^{30} \mathrm{Si}$ distribution remains out of reach. This situation is unfortunate, since a good handle on the Pacific $\delta^{30} \mathrm{Si}$ distribution is needed to draw robust conclusions regarding the controls on the global-scale $\delta^{30} \mathrm{Si}$ distribution, and the oceanic Si cycle that it reflects. Nonetheless, our own data document low $\delta^{30} \mathrm{Si}$ variability at densities associated with the lower cell of the MOC, including high-[Si] waters returning from the North Pacific Ocean. This constancy suggests that the $\delta^{30} \mathrm{Si}$ values of deep waters are not strongly altered by opal dissolution along their deep circulation path, i.e., that large variations in deep water $\delta^{30} \mathrm{Si}$ signatures require the introduction of a preformed $\delta^{30} \mathrm{Si}$ signal. This would mean that the ultimate cause of most subsurface seawater $\delta^{30} \mathrm{Si}$ variability in the global ocean is the fractionation of $\mathrm{Si}$ isotopes between the upper and lower limbs of the MOC in the surface Southern Ocean (Sect. 5.1 and de Souza et al., 2012). This conclusion must, however, remain tentative until the deep North Pacific $\delta^{30} \mathrm{Si}$ distribution is better constrained.

\section{Summary and conclusions}

This study presents the first $\delta^{30} \mathrm{Si}$ data from the eastern South Pacific and the Pacific sector of the Southern Ocean, a region that plays an important role in the ventilation of the mid- and low-latitude thermocline. Our analysis traces the incorporation of high $\delta^{30} \mathrm{Si}$ values into AAIW and SAMW, and their export to the base of the subtropical thermocline, as previously inferred (de Souza et al., 2012). Within the subtropical ocean interior, the $\delta^{30} \mathrm{Si}$ distribution documents the dominant influence of the spreading of AAIW and SAMW in determining the mesopelagic $\delta^{30} \mathrm{Si}$ distribution, tracing the important contribution of the preformed component to the $\mathrm{Si}$ inventory of the well-ventilated eastern South Pacific. The data also reveal that the high $\delta^{30} \mathrm{Si}$ signature of SAMW/AAIW is not conserved in the equatorial Pacific Ocean, analogous to the observations of the stable nitrogen isotope composition of nitrate by Rafter et al. (2012). The marked change in the lower thermocline and intermediate ${ }^{30} \mathrm{Si}$ distribution between the subtropics and tropics appears to record two phenomena: a switch in the dominant source of Si from the Southern Ocean to the North Pacific (Dugdale et al., 2002; Sarmiento et al., 2004), and the accumulation of remineralized $\mathrm{Si}$ in the shadow zone of the eastern equatorial Pacific. The clear difference between the mesopelagic ${ }^{30} \mathrm{Si}$ distribution in these two regions demonstrates that seawater $\delta^{30} \mathrm{Si}$ values trace $\mathrm{Si}$ cycling and transport within the ocean, and that the signal they record must be interpreted in the context of water mass history.

The low variability of $\delta^{30} \mathrm{Si}$ values in deep South Pacific waters denser than $\gamma^{\mathrm{n}}=27.7 \mathrm{~kg} \mathrm{~m}^{-3}$, which circulate within the lower limb of the meridional overturning circulation (Lumpkin and Speer, 2007), suggests that the dissolution of opal plays a negligible role in altering deep water $\delta^{30} \mathrm{Si}$ values. However, the certainty of this conclusion is undermined by uncertainties that still exist regarding the deep Pacific $\delta^{30} \mathrm{Si}$ distribution, especially in the North Pacific. A detailed study of the meridional and/or zonal $\delta^{30} \mathrm{Si}$ distribution in the North Pacific, including its high-Si plume, is needed before this conclusion can be robustly confirmed.

\section{Supplementary material related to this article is available online at: http://www.biogeosciences.net/9/ 4199/2012/bg-9-4199-2012-supplement.zip.}


Acknowledgements. William Landing is gratefully acknowledged for collecting samples for $\delta^{30} \mathrm{Si}$ analysis from the CLIVAR I06S re-occupation. Cruises 33RO20071215 and 33RR20080204 were undertaken as part of the US Repeat Hydrography Program funded by NSF/NOAA; the authors wish to thank the captains and crews of R/V Ronald H. Brown and Roger Revelle as well as K. Speer as Chief Scientist on cruise 33RR20080204. Bottle data were accessed from data files p18_33RO20071215_hy1.csv (dated 20111215) and i06s_33RR20080204_hy1.csv (dated 20110904), CLIVAR and Carbon Hydrographic Data Office, La Jolla, CA, USA; the contributions of Molly Baringer, Calvin Mordy, Jia-Zhong Zhang, Chris Langdon, and Mark Warner toward producing these data are acknowledged. The authors thank Damien Cardinal and an anonymous reviewer for their constructive reviews, and Christine Klaas for editorial handling. This study was supported by Swiss National Science Foundation grants 200021-116473 and 200020-130361.

Edited by: C. Klaas

\section{References}

Antonov, J. I., Seidov, D., Boyer, T. P., Locarnini, R. A., Mishonov, A., and Garcia, H. E.: World Ocean Atlas 2009, vol. 2, Salinity, NOAA Atlas NESDIS 69, US Government Printing Office, Washington DC, 2010.

Aoki, S., Hariyama, M., Mitsudera, H., Sasaki, H., and Sasai, Y.: Formation regions of Subantarctic Mode Water detected by OFES and Argo profiling floats, Geophys. Res. Lett., 34, L10606, doi:10.1029/2007g1029828, 2007.

Beucher, C. P., Brzezinski, M. A., and Jones, J. L.: Sources and biological fractionation of Silicon isotopes in the Eastern Equatorial Pacific, Geochim. Cosmochim. Ac., 72, 3063-3073, 2008.

Beucher, C. P., Brzezinski, M. A., and Jones, J. L.: Mechanisms controlling silicon isotope distribution in the Eastern Equatorial Pacific, Geochim. Cosmochim. Ac., 75, 4286-4294, 2011.

Blanco, J. L., Thomas, A. C., Carr, M.-E., and Strub, P. T.: Seasonal climatology of hydrographic conditions in the upwelling region of Northern Chile, J. Geophys. Res.-Oceans, 106, 11451-11467, 2001.

Broecker, W. S., Blanton, S., Smethie, W. M., and Ostlund, G.: Radiocarbon decay and oxygen utilization in the deep Atlantic Ocean, Global Biogeochem. Cy., 5, 87-117, 1991.

Brzezinski, M. A., Jones, J. L., Beucher, C. P., Demarest, M. S., and Berg, H. L.: Automated determination of silicon isotope natural abundance by the acid decomposition of cesium hexafluosilicate, Anal. Chem., 78, 6109-6114, 2006.

Brzezinski, M. A., Dumousseaud, C., Krause, J. W., Measures, C. I., and Nelson, D. M.: Iron and silicic acid concentrations together regulate Si uptake in the equatorial Pacific Ocean, Limnol. Oceanogr., 53, 875-889, 2008.

Buesseler, K. O.: The decoupling of production and particulate export in the surface ocean, Global Biogeochem. Cy., 12, 297-310, 1998.

Cardinal, D., Alleman, L. Y., Dehairs, F., Savoye, N., Trull, T. W., and Andre, L.: Relevance of silicon isotopes to Si-nutrient utilization and Si-source assessment in Antarctic waters, Global Biogeochem. Cy., 19, GB2007, doi:10.1029/2004GB002364, 2005.
Cavagna, A.-J., Fripiat, F., Dehairs, F., Wolf-Gladrow, D. A., Cisewski, B., Savoye, N., André, L., and Cardinal, D.: Silicon uptake and supply during a Southern Ocean iron fertilization experiment (EIFEX) tracked by Si isotopes, Limnol. Oceanogr., 56, 147-160, 2011.

De La Rocha, C. L., Brzezinski, M. A., and DeNiro, M. J.: Fractionation of silicon isotopes by marine diatoms during biogenic silica formation, Geochim. Cosmochim. Ac., 61, 5051-5056, 1997.

De La Rocha, C. L., Brzezinski, M. A., and DeNiro, M. J.: A first look at the distribution of the stable isotopes of silicon in natural waters, Geochim. Cosmochim. Ac., 64, 2467-2477, 2000.

de Souza, G. F., Reynolds, B. C., Rickli, J., Frank, M., Saito, M., Gerringa, L. J. A., and Bourdon, B.: Southern Ocean control of silicon stable isotope distribution in the deep Atlantic Ocean, Global Biogeochem. Cy., 26, GB2035, doi:10.1029/2011GB004141, 2012.

Dong, S., Sprintall, J., Gille, S. T., and Talley, L.: Southern Ocean mixed-layer depth from Argo float profiles, J. Geophys. Res.Oceans, 113, C06013, doi:10.1029/2006jc004051, 2008.

Dugdale, R. C., Wischmeyer, A. G., Wilkerson, F. P., Barber, R. T., Chai, F., Jiang, M. S., and Peng, T. H.: Meridional asymmetry of source nutrients to the equatorial Pacific upwelling ecosystem and its potential impact on ocean-atmosphere $\mathrm{CO}_{2}$ flux; a data and modeling approach, Deep-Sea Res. Pt. II, 49, 2513-2531, 2002.

Ehlert, C., Grasse, P., Mollier-Vogel, E., Böschen, T., Franz, J., de Souza, G. F., Reynolds, B. C., Stramma, L., and Frank M.: Factors controlling the silicon isotope distribution in waters and surface sediments of the Peruvian coastal upwelling, Geochim. Cosmochim. Ac., 99, 128-145, 2012.

Fine, R. A., Maillet, K. A., Sullivan, K. F., and Willey, D.: Circulation and ventilation flux of the Pacific Ocean, J. Geophys. Res.-Oceans, 106, 22159-22178, 2001.

Fripiat, F., Cavagna, A.-J., Dehairs, F., Speich, S., André, L., and Cardinal, D.: Silicon pool dynamics and biogenic silica export in the Southern Ocean inferred from Si-isotopes, Ocean Sci., 7, 533-547, doi:10.5194/os-7-533-2011, 2011a.

Fripiat, F., Cavagna, A.-J., Savoye, N., Dehairs, F., André, L., and Cardinal, D.: Isotopic constraints on the Si-biogeochemical cycle of the Antarctic Zone in the Kerguelen area (KEOPS), Mar. Chem., 123, 11-22, 2011b.

Garcia, H. E., Locarnini, R. A., Boyer, T. P., and Antonov, J. I.: World Ocean Atlas 2009, vol. 3, Dissolved Oxygen, Apparant Oxygen Utilization, and Oxygen Saturation, NOAA Atlas NESDIS 70, US Government Printing Office, Washington DC, 2010a.

Garcia, H. E., Locarnini, R. A., Boyer, T. P., and Antonov, J. I.: World Ocean Atlas 2009, vol. 4, Nutrients (phosphate, nitrate, silicate), NOAA Atlas NESDIS 71, US Government Printing Office, Washington DC, 2010b.

Georg, R., Reynolds, B., Frank, M., and Halliday, A.: New sample preparation techniques for the determination of Si isotopic compositions using MC-ICPMS, Chem. Geol., 235, 95-104, 2006.

Gruber, N., Gloor, M., Mikaloff Fletcher, S. E., Doney, S. C., Dutkiewicz, S., Follows, M. J., Gerber, M., Jacobson, A. R., Joos, F., Lindsay, K., Menemenlis, D., Mouchet, A., Müller, S. A., Sarmiento, J. L., and Takahashi, T.: Oceanic sources, sinks, and transport of atmospheric $\mathrm{CO}_{2}$, Global Biogeochem. Cy., 23, GB1005, doi:10.1029/2008gb003349, 2009. 
Hanawa, K. and Talley, L. D.: Mode waters, in: Ocean Circulation and Climate - Observing and Modelling the Global Ocean, edited by: Siedler, G., Church, J. A., and Gould, J., vol. 77 of International Geophysics, Academic Press, San Diego, 373-386, 2001.

Jackett, D. R. and McDougall, T. J.: A neutral density variable for the world's oceans, J. Phys. Oceanogr., 27, 237-263, 1997.

Johnson, G. C.: Quantifying antarctic bottom water and North Atlantic deep water volumes, J. Geophys. Res.-Oceans, 113, C05027, doi:10.1029/2007JC004477, 2008.

Johnson, G. C. and McPhaden, M. J.: Interior pycnocline flow from the subtropical to the equatorial Pacific Ocean, J. Phys. Oceanogr., 29, 3073-3089, 1999.

Johnson, G. C. and McTaggart, K. E.: Equatorial Pacific $13^{\circ} \mathrm{C}$ Water eddies in the eastern subtropical South Pacific Ocean, J. Phys. Oceanogr., 40, 226-236, 2010.

Karstensen, J. and Quadfasel, D.: Formation of southern hemisphere thermocline waters: water mass conversion and subduction, J. Phys. Oceanogr., 32, 3020-3038, 2002.

Karstensen, J., Stramma, L., and Visbeck, M.: Oxygen minimum zones in the eastern tropical Atlantic and Pacific oceans, Prog. Oceanogr., 77, 331-350, 2008.

Locarnini, R. A., Mishonov, A., Antonov, J. I., Boyer, T. P., and Garcia, H. E.: World Ocean Atlas 2009, vol. 1, Temperature, NOAA Atlas NESDIS 68, US Government Printing Office, Washington DC, 2010.

Lumpkin, R. and Speer, K.: Global ocean meridional overturning, J. Phys. Oceanogr., 37, 2550-2562, 2007.

Matsumoto, K.: Radiocarbon-based circulation age of the world oceans, J. Geophys. Res.-Oceans, 112, C09004, doi:10.1029/2007JC004095, 2007.

McCartney, M. S.: Subantarctic mode water, in: A Voyage of Discovery, Supplement to Deep-Sea Research vol. 24, edited by: Angel, M., Pergamon Press, Oxford, 103-119, 1977.

McCartney, M. S.: The subtropical recirculation of Mode Waters, J. Mar. Res., 40, 427-464, 1982.

Milligan, A. J., Varela, D. E., Brzezinski, M. A., and Morel, F. M. M.: Dynamics of silicon metabolism and silicon isotopic discrimination in a marine diatom as a function of $p \mathrm{CO}_{2}$, Limnol. Oceanogr., 49, 322-329, 2004.

O'Connor, B. M., Fine, R. A., Maillet, K. A., and Olson, D. B.: Formation rates of subtropical underwater in the Pacific Ocean, Deep-Sea Res. Pt. I, 49, 1571-1590, 2002.

Orsi, A. H., Whitworth, T., and Nowlin, W. D.: On the meridional extent and fronts of the Antarctic Circumpolar Current, Deep-Sea Res. Pt. I, 42, 641-673, 1995.

Palter, J. B., Sarmiento, J. L., Gnanadesikan, A., Simeon, J., and Slater, R. D.: Fueling export production: nutrient return pathways from the deep ocean and their dependence on the Meridional Overturning Circulation, Biogeosciences, 7, 3549-3568, doi:10.5194/bg-7-3549-2010, 2010.

Rafter, P. A., Sigman, D. M., Charles, C. D., Kaiser, J., and Haug, G. H.: Subsurface tropical Pacific nitrogen isotopic composition of nitrate: Biogeochemical signals and their transport, Global Biogeochem. Cy., 26, GB1003, doi:10.1029/2010gb003979, 2012.

Reid, J. L.: On the total geostrophic circulation of the South Pacific Ocean: flow patterns, tracers and transports, Prog. Oceanogr., 16, 1-61, 1986.
Reid, J. L.: On the total geostrophic circulation of the Pacific Ocean: flow patterns, tracers, and transports, Prog. Oceanogr., 39, 263 352, 1997.

Reynolds, B. C., Frank, M., and Halliday, A. N.: Silicon isotope fractionation during nutrient utilization in the North Pacific, Earth Planet. Sc. Lett., 244, 431-443, 2006.

Reynolds, B. C., Aggarwal, J., André, L., Baxter, D., Beucher, C., Brzezinski, M. A., Engström, E., Georg, R. B., Land, M., Leng, M. J., Opfergelt, S., Rodushkin, I., Sloane, H. J., van den Boorn, S. H. J. M., Vroon, P. Z., and Cardinal, D.: An interlaboratory comparison of $\mathrm{Si}$ isotope reference materials, J. Anal. Atom. Spectrom., 22, 561-568, 2007.

Sallée, J.-B., Speer, K., Rintoul, S., and Wijffels, S.: Southern Ocean thermocline ventilation, J. Phys. Oceanogr., 40, 509-529, 2010.

Sarmiento, J. L., Gruber, N., Brzezinski, M. A., and Dunne, J. P.: High-latitude controls of thermocline nutrients and low latitude biological productivity, Nature, 427, 56-60, 2004.

Schlitzer, R.: Electronic atlas of WOCE hydrographic and tracer data now available, EOS T. Am. Geophys. Un., 81, p. 45, doi:10.1029/00EO00028, 2000.

Schlitzer, R.: Ocean Data View, available at: http://odv.awi.de, 2009.

Schmitz, W. J.: The Pacific and Indian Oceans/A Global Update, Technical report, Woods Hole Oceanographic Institution, Woods Hole, Massachusetts 02543, USA, 1996.

Sloyan, B. M. and Rintoul, S. R.: Circulation, renewal, and modification of Antarctic mode and intermediate water, J. Phys. Oceanogr., 31, 1005-1030, 2001.

Sloyan, B. M., Talley, L. D., Chereskin, T. K., Fine, R., and Holte, J.: Antarctic intermediate water and subantarctic mode water formation in the Southeast Pacific: the role of turbulent mixing, J. Phys. Oceanogr., 40, 1558-1574, 2010.

Stommel, H.: Determination of water mass properties of water pumped down from the Ekman layer to the geostrophic flow below, P. Natl. Acad. Sci. USA, 76, 3051-3055, 1979.

Talley, L. D. and Joyce, T. M.: The double silica maximum in the North Pacific, J. Geophys. Res.-Oceans, 97, 5465-5480, 1992.

Toggweiler, J. R. and Carson, S.: What are upwelling systems contributing to the ocean's carbon and nutrient budgets?, in: Upwelling in the Ocean: Modern Processes and Ancient Records, edited by: Summerhayes, C., Emeis, K.-C., Angel, M. V., Smith, R. L., and Zeitzschel, B., John Wiley and Sons, Chichester, 337-360, 1995.

Toggweiler, J. R., Dixon, K., and Broecker, W. S.: The Peru upwelling and the ventilation of the South Pacific thermocline, J. Geophys. Res.-Oceans, 96, 20467-20497, 1991.

Tsuchiya, M.: Flow path of Antarctic Intermediate Water in the western equatorial South Pacific Ocean, Deep-Sea Res., 38, S273-S279, 1991.

Tsuchiya, M. and Talley, L.: Water-property distributions along an Eastern Pacific hydrographic section at 135 W, J. Mar. Res., 54, 541-564, 1996.

Tsuchiya, M. and Talley, L. D.: A Pacific hydrographic section at $88^{\circ} \mathrm{W}$ : water-property distribution, J. Geophys. Res.-Oceans, 103, 12899-12918, 1998.

Tsuchiya, M., Lukas, R., Fine, R. A., Firing, E., and Lindstrom, E.: Source waters of the Pacific Equatorial Undercurrent, Prog. Oceanogr., 23, 101-147, 1989. 
Varela, D. E., Pride, C. J., and Brzezinski, M. A.: Biological fractionation of silicon isotopes in Southern Ocean surface waters, Global Biogeochem. Cy., 18, GB1047, doi:10.1029/2003GB002140, 2004.
Warren, B. A.: Transpacific hydrographic sections at Lats. $43^{\circ} \mathrm{S}$ and $28^{\circ} \mathrm{S}$ : the SCORPIO expedition - II. Deep water, Deep Sea Res. Ocean., 20, 9-38, 1973.

Wong, A. P. S. and Johnson, G. C.: South Pacific eastern subtropical mode water, J. Phys. Oceanogr., 33, 1493-1509, 2003. 